\section{Fertility Rate of Seacoast Marshelder Stock Plants Influences Cutting Production and Rooting Characteristics of Stem Cuttings}

\author{
Josiah Raymer ${ }^{1}$, Mack Thetford ${ }^{2,4}$, and Debbie L. Miller ${ }^{3}$
}

ADDITIONAL INDEX WORDS. indole-3-butyric acid, auxin, stock plant hedging, Iva imbricata

SuMMARY. Seacoast marshelder (Iva imbricata) is an important coastal species contributing to building of foredunes along the Gulf of Mexico coastal regions. Hurricane activity disrupts natural regeneration, and the need for successful nursery production of sufficient plants for restoration warrants development of efficient propagation and production practices for restoration efforts. The objectives of these experiments were to investigate the effects of stock plant fertility on cutting production of seacoast marshelder and to evaluate the rooting qualities of cuttings harvested from hedged stock. Stock plants were established in 1 -gal containers using a pine bark substrate amended with $6 \mathrm{lb} /$ yard $^{3}$ dolomitic limestone. Plants were fertilized with $15 \mathrm{~N}-3.9 \mathrm{P}-10 \mathrm{~K}$ controlled-release fertilizer (Osmocote Plus, 8- to 9 -month formulation at $21^{\circ} \mathrm{C}$ ) applied as a top dressing at the recommended full label rate of $11 \mathrm{~g}$ per pot and $5.5,15$, and $21 \mathrm{~g}$ per pot (12 pots each) using a completely randomized design. Cuttings were collected and stock plants hedged on a regular interval [Expt. 1 (May to August) and Expt. 2 (August to November)]. Hedging of stock plants reduced height to $20 \mathrm{~cm}$ after each successive harvest of cuttings, but stock plant growth index increased with each successive harvest. Stock plant growth and cutting production increased as fertility rate increased, but responses were not consistent across harvest times. This trend was also true for rooting percentage and measures of root quality. Seacoast marshelder stock plant size increased as fertility increased to $15 \mathrm{~g}$ but not at $21 \mathrm{~g}$. Inconsistencies in rooting responses across the production period were evident and were attributed to seasonal growth effects. An inverse relationship between rooting percentage and fertility rate was evident from May through July suggesting high levels of fertility should be avoided because rooting percentage, root number, and root length were reduced as fertility rate increased during that time. Conversely, higher fertilizer rates had a neutral to positive effect on rooting of seacoast marshelder during the months of August through November.

S eacoast marshelder is a dominant seashore plant that occurs on coastal dunes throughout the southern Atlantic and Gulf of Mexico coastal regions. Seacoast marshelder spread can be vegetative and by seed and has been identified as the only broadleaved plant with a potential for building and stabilizing foredunes in the southern Atlantic coast of the United States (Woodhouse, 1982). Seacoast marshelder can grow throughout foredune and backdune

University of Florida, Environmental Horticulture, 5988 Highway 90, Building 4900, Milton, FL 32583

This paper is from a thesis submitted by Josiah Raymer in partial fulfillment of the requirements for the MS degree.

${ }^{1}$ Research Assistant. Environmental Horticulture Department.

${ }^{2}$ Associate Professor. Environmental Horticulture Department.

${ }^{3}$ Associate Professor. Wildlife Ecology and Conservation Department.

${ }^{4}$ Corresponding author. E-mail: thetford@ufl.edu. vegetation zones and is occasionally found alone in building foredunes. More often, seacoast marshelder is found in combination with one or more dune-building grasses (Woodhouse, 1982). Seacoast marshelder is used for dune restoration and stabilization projects (Craig, 1991) and has also been identified as an important food for beach mice (Peromyscus polionotus) (Moyers, 1996).

Seacoast marshelder is a perennial C3 shrub (Franks, 2003), which produces inflorescences at the tips of its stems in the fall. The species has sparse woody stems from 1 to $4 \mathrm{ft}$ tall with fleshy, narrow, lance-shaped leaves with a thick cuticle. Highest rates of seed production on mature plants occur in foredunes, whereas successful seedling establishment occurs in areas of little sand movement and favorable moisture (Woodhouse, 1982) causing highest germination rates to occur on open beach or upper marsh in the spring (Colosi and McCormick, 1978). Van der Valk (1974) determined that germination is limited to conditions where no more than $4 \mathrm{~cm}$ of sand accumulates above the seed and that mature plants present on foredunes were derived from seedlings established before dune formation. Sand accumulated around seacoast marshelder as it grew resulting in dune formation. Seacoast marshelder develops a strong system of rhizomes and roots when buried by sand and produces gently rounded dunes (Craig, 1991). Although these growth characteristics make this species desirable for dune restoration, the availability of plants after storm events and timing of seed production in natural regeneration may not provide sufficient plants for restoration and warrants development of efficient propagation and production practices for restoration efforts.

The phenology of seacoast marshelder influences the availability of viable stem cuttings. Plants along the Gulf of Mexico coastal regions are dormant during the winter with the first leaves appearing in mid- to late March depending on the degree of exposure. Leaf arrangement in early spring is opposite and leaves are nearly half as broad as long, very thick, and fleshy. Within a few weeks, leaf arrangement becomes alternate, internodes become longer, and leaf length, width, and thickness decrease. Flower buds begin to appear by July and flowers open in August and September followed by fruit

\begin{tabular}{llll}
\hline $\begin{array}{l}\text { Units } \\
\text { To convert U.S. to SI, } \\
\text { multiply by }\end{array}$ & U.S unit & SI unit & $\begin{array}{l}\text { To convert SI to U.S., } \\
\text { multiply by }\end{array}$ \\
\hline 0.3048 & $\mathrm{ft}$ & $\mathrm{m}$ & 3.2808 \\
3.7854 & $\mathrm{gal}$ & $\mathrm{L}$ & 0.2642 \\
2.54 & inch(es) & $\mathrm{cm}$ & 0.3937 \\
0.5933 & $\mathrm{lb} / \mathrm{yard}^{3}$ & $\mathrm{~kg} \cdot \mathrm{m}^{-3}$ & 1.6856 \\
28.3495 & $\mathrm{Oz}$ & $\mathrm{g}$ & 0.0353 \\
1 & $\mathrm{ppm}$ & $\mathrm{mg} \cdot \mathrm{L}^{-1}$ & 1 \\
$\left({ }^{\circ} \mathrm{F}-32\right) \div 1.8$ & ${ }^{\circ} \mathrm{F}$ & ${ }^{\circ} \mathrm{C}$ & $\left(1.8 \times{ }^{\circ} \mathrm{C}\right)+32$
\end{tabular}


development and seed maturation in October. The authors have observed a lack of vegetative bud development for rooted cuttings derived from terminal inflorescences suggesting a limited period of cutting collection from native populations between April and August.

Softwood cuttings of seacoast marshelder stems root readily (Craig, 1991) with rooting percentages greater than $90 \%$ achievable with or without auxin application for $10-\mathrm{cm}$ cuttings collected from native populations (Thetford and Miller, 2002). Management of stock plants in a nursery setting is desirable for producing a reliable and consistent source of cuttings. However, it is not presently known if container production of stock plants for this purpose is a viable alternative or if stock plant fertility may have an effect on cutting production, rooting percentage, or the quantity or quality of the roots produced.

Stock plant nutrition and fertility have been shown to be factors in the rooting of softwood and hardwood cuttings (Blazich, 1988; Veierskov, 1988). For example, cuttings of geranium (Pelargonium spp.) harvested from stock plants grown under low and medium fertility rates [nitrogen (N), phosphorus, potassium] demonstrated an increase in rooting percentage compared with high fertility rates (Blazich, 1988; Haun and Cornell, 1951; Veierskov, 1988). A similar response was noted by Preston et al. (1953) when propagating azalea (Rhododendron spp.) maintained under similar fertility rates where low and medium rates demonstrated higher rooting percentages than high fertility rates. Optimum stock plant $\mathrm{N}$ levels for rooting of cuttings has also been shown to occur below the optimum level for stock plant growth for eastern red cedar (Juniperus virginiana) where optimum growth occurred at 100 to $150 \mathrm{mg} \cdot \mathrm{L}^{-1} \mathrm{~N}$, whereas the optimum rooting occurred at 20 to $40 \mathrm{mg} \cdot \mathrm{L}^{-1} \mathrm{~N}$ (Henry et al., 1992). Cutting production has also been shown to increase with successive harvests in response to hedging of stock plants (Faust and Grimes, 2005). Utilization of hedged stock plants should be evaluated as a method of increasing cutting production.

This previous work demonstrates a need to consider not only the effects of fertilization on the number of cuttings produced, but to consider also the effects of stock plant fertility on the rooting success of cuttings when optimizing stock plant fertility rates. Finding an acceptable level of stock plant fertility to maximize cutting production without sacrificing root quality will lead to better management practices. The objectives of the following experiments were to investigate the effects of stock plant fertility on cutting production of seacoast marshelder and to evaluate the rooting qualities of cuttings harvested from hedged stock plants.

\section{Materials and methods}

Forty-eight stock plants of seacoast marshelder were planted on both 3 Feb. 2004 (Expt. 1) and 9 July 2004 (Expt. 2) using 4-inchdiameter liner pots (Thetford and Miller, 2002) transplanted into 1-gal containers. Dormant liners (transplants had no active shoot growth) were used to initiate Expt. 1, whereas Expt. 2 was initiated during the growing season (transplants were actively growing). Liners were grown in a pine bark substrate amended with $6 \mathrm{lb} /$ yard $^{3}$ dolomitic limestone. Plants were pruned to $8 \mathrm{~cm}$ in height $7 \mathrm{~d}$ after planting (DAP).

Plants were fertilized with $15 \mathrm{~N}-$ $3.9 \mathrm{P}-10 \mathrm{~K}$ controlled-release fertilizer (8- to 9-month formulation at $21{ }^{\circ} \mathrm{C}$, Osmocote Plus; Scotts MiracleGrow, Marysville, $\mathrm{OH}$ ) applied as a top dressing at the recommended full label rate of $11 \mathrm{~g}$ per 1 -gal pot and $5.5,15$, and $21 \mathrm{~g}$ per 1 -gal pot. Plants were grown in full sun receiving $30 \mathrm{~min}$ of overhead irrigation twice daily. Each of the two experiments was a completely randomized design consisting of four fertility treatments with 12 singleplant replications.

First harvest of cuttings was conducted when all of the stock plants in the experiment had sufficient growth to collect at least four $10-\mathrm{cm}$-long cuttings. The first harvest of cuttings from each experiment began 114 (April) and 49 (August) DAP, respectively. Stock plants were evaluated for shoot growth and total cutting production at each of four harvest dates $[114,146,175$, and 206 DAP for Expt. 1 (April to August) and 49, 79,
108, and 136 DAP for Expt. 2 (August to November)]. Each plant was measured for maximum shoot height and width (mean of two perpendicular widths) and all tip cuttings $10 \mathrm{~cm}$ in length harvested. The total number and total weight (grams) of cuttings collected from each plant were recorded and the stock plants were hedged to a height of $20 \mathrm{~cm}$.

Cuttings were stripped of leaves $2 \mathrm{~cm}$ above the base and a fresh cut made before treatment with 1000 $\mathrm{mg} \cdot \mathrm{L}^{-1}$ indole-3-butyric acid (Hormodin 1; OHP, Mainland, PA). Each rooting experiment contained four cuttings from each of the 12 stock plants representing each of the four fertilizer treatments for a total of 192 cuttings. However, the first harvest of Expt. 2 did not yield sufficient cuttings so no rooting data are available for that date. All rooting experiments were arranged in a randomized complete block design with each of the 12 blocks containing 16 cuttings.

Cuttings were inserted $2 \mathrm{~cm}$ deep into 72 -cell plug flats filled with a soilless production mix $(40 \%$ peat, $35 \%$ vermiculite, $25 \%$ bark, Fafard \#4M Mix; Conrad Fafard, Agawam, MA). Cuttings were placed under intermittent mist operating at $4 \mathrm{~s}$ of mist every $10 \mathrm{~min}$ from 0700 to 2000 $\mathrm{HR}$ with bottom heat of $80{ }^{\circ} \mathrm{F}$.

Cuttings were evaluated for rooting $14 \mathrm{~d}$ after sticking. Roots were washed free of propagation substrate and root number (primary roots emerging from the cutting) and length of the longest root (centimeters) was recorded for each cutting. Rooting characteristics of cuttings were quantified using a subsample of four cuttings randomly selected from the pool of cuttings taken from each stock plant at each harvest.

Mean fresh weight per cutting was calculated for each stock plant using total fresh weight of all cuttings harvested divided by total number of cuttings harvested. A plant growth index was calculated for each stock plant using plant height and width $[$ (mean plant width + plant height $) /$ 2 ] to evaluate the combined effects of changes in height and width and to monitor overall changes in plant growth. Rooting percentage for each stock plant was calculated as the number of cuttings rooted divided by the number of cuttings stuck. 
The timing of the two experiments resulted in stock plants exhibiting differing seasonal growth effects associated with the changing morphology of the plants at the time of experiment initiation. Hence, cuttings from harvests one to four of each experiment differ in morphology, necessitating results of the two experiments be presented separately. Data from each experiment were analyzed separately with significance of main effects (fertility rate and harvest date) and interactions determined using the Proc Mixed procedures of SAS (v8.0; SAS Institute, Cary, NC) to accommodate the repeated measures design of the experiment. Data for all response variables were regressed on main effects of fertility rate or harvest date using the regression procedure of SAS. Relationships between variables were assessed using the Proc Corr procedure of SAS with significant Pearson correlation coefficients reported in the text. An alpha level of $5 \%$ or less was considered significant in all statistical tests. Residual analysis was conducted and assumptions of equal variance and normality were met (skewness near 0 ) for all data with the exception of percent rooting. Unequal variances were stabilized with an arcsine square root transformation.

\section{Results}

Phenology of nursery-grown seacoast marshelder reflected the seasonal transition in morphology noted previously with native populations. Initial growth of dormant and actively growing stock plants in this experiment reflected leaf morphology and arrangement consistent with plants previously observed in the coastal environment at the respective potting times. These marked seasonal differences in morphology were expected and reflected in the mean fresh weight per cutting.

\section{Expt. 1: Dormant transplants}

STOCK PLANT GROWTH AND CUTTING PRODUCTION. For stock plants initiated from dormant liners, the main effects of fertility and harvest date both had a significant effect on stock plant size as shown by changes in height, width, and growth index (Fig. 1). There were significant interactions between the effects of fertility and harvest date for all variables
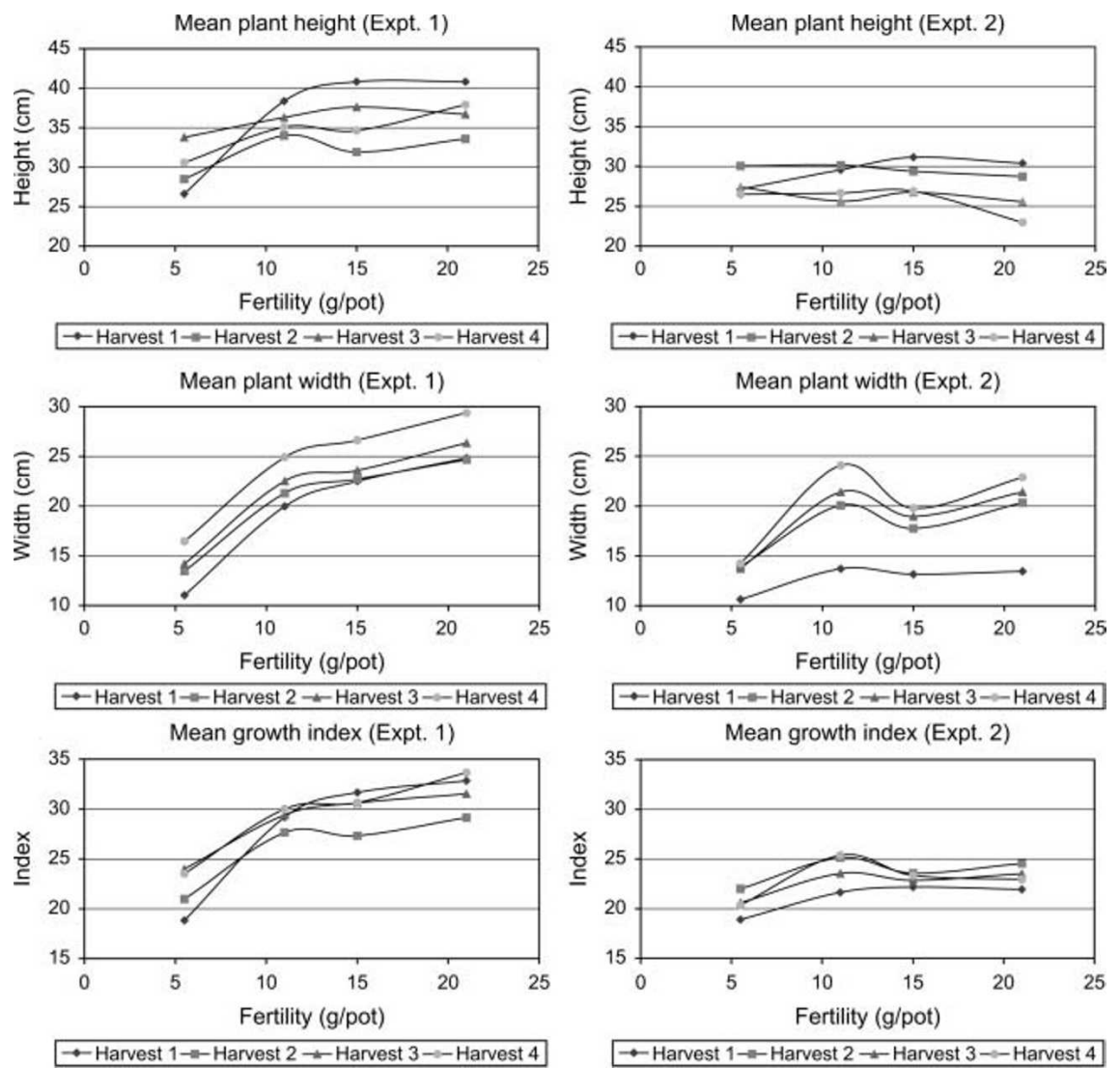

Fig. 1. Mean height, width, and growth index [(mean width + height $) / 2]$ for seacoast marshelder stock plants planted 3 Feb. 2004 (Expt. 1) and 9 July 2004 (Expt. 2) fertilized at 5.5, 11, 15, or $21 \mathrm{~g}$ of $15 \mathrm{~N}-3.9 \mathrm{P}-10 \mathrm{~K}$ controlled-release fertilizer [Osmocote Plus, 8- to 9-month formulation at $70{ }^{\circ} \mathrm{F}\left(21.1^{\circ} \mathrm{C}\right)$; Scotts Miracle-Grow, Marysville, $\mathrm{OH}$ ] per 1 -gal $(3.8 \mathrm{~L})$ pot and hedged monthly (May to August and August to November) to harvest cuttings $(1 \mathrm{~cm}=0.3937 \mathrm{inch}$, $1 \mathrm{~g}=0.0353 \mathrm{oz})$.

except stock plant width. Pearson correlation coefficients indicate stock plant height and width were not correlated, although both were highly correlated with the growth index $(\mathrm{r}=$ 0.858 and 0.816 , respectively).

Stock plant height increased as fertility rate increased for all harvests (Fig. 1). There was a significant decrease in stock plant height for all harvest periods when fertility rate decreased from 11 to $5.5 \mathrm{~g}$. Before the first harvest of cuttings, maximum height was achieved between 11 and $15 \mathrm{~g}$, but plant height did not differ among the 11,15 , and $21 \mathrm{~g}$ fertilizer rates after initiation of stock plant hedging.

Stock plant width also increased as fertility rate increased for all harvest dates (Fig. 1). There was a significant decrease in stock plant width for all harvest dates when fertility decreased to $5.5 \mathrm{~g}$. Plant width did not differ among plants fertilized at 11 and
$15 \mathrm{~g}$; however, there was a significant increase in plant width when the fertility rate was increased to $21 \mathrm{~g}$ when compared with $11 \mathrm{~g}$.

Fertility had a significant positive effect on stock plant growth index (Fig. 1). The greatest response was evident before the first harvest of cuttings when plant growth index decreased $35 \%$ when fertilizer was applied at $5.5 \mathrm{~g}$, whereas a $13 \%$ increase in plant growth index was evident at $21 \mathrm{~g}$. After the initial harvest of cuttings, plant growth index did not differ among plants fertilized at 11 and $15 \mathrm{~g}$. The data suggest an application of slow-release fertilizer nearly twice the recommended rate is necessary to affect a significant increase in plant growth index for seacoast marshelder stock plants.

Although hedging of stock plants reduced height to $20 \mathrm{~cm}$ after each successive harvest of cuttings, stock plant growth index (Fig. 1) 
increased with each successive harvest $(P<0.0001)$. The effect of increasing stock plant width was a $5 \%$ increase in growth index from May to August.

Fertility rate as well as time of harvest had a significant effect on the total fresh weight of cuttings removed from each plant $(P<$ $0.0001)$. The total fresh weight of cuttings produced per stock plant increased linearly with an increase in fertilizer rate for all harvests (Fig. 2). When stock plants were produced at the 11-g fertility rate, total fresh weight of cuttings decreased 35\% between May and July, but total fresh weight of cuttings increased $27 \%$ between July and August.

Fertility rate had a significant effect on cutting number $(P<0.0001)$. The number of cuttings produced per stock plant increased linearly with increasing rate of fertility for all harvests (Fig. 2). The number of cuttings produced per stock plant at $11 \mathrm{~g}$ increased with each successive harvest $(P<0.0001)$, resulting in a 93\% increase in the number of cuttings produced per stock plant from May to August (Fig. 2). Pearson correlation coefficients indicate the number of cuttings produced was not correlated with plant height $(r=0.2539)$ or index $(\mathrm{r}=0.5733)$, but was highly correlated with plant width $(\mathrm{r}=$ 0.74923 ) across harvests. This suggests stock plant width had a greater positive effect on increases in cutting production than stock plant height and managing stock plants in a fashion that increased width increased cutting production.

Fertility rate and time of harvest had a significant effect on the weight of individual cuttings $(P<0.0001)$. For the initial harvest in May, the weight of individual cuttings was $53 \%$ to $56 \%$ higher than at other harvests (Fig. 3). The weight of cuttings harvested in May and June increased linearly with an increase in fertilizer rate and cutting weight increased $24 \%$ and $10 \%$ with a doubling of the fertility (Fig. 3). Weight of individual cuttings did not differ in July and August.

ROOTING PERCENTAGES AND QUALITY. An interaction was present between the main effects of fertility and time of harvest for rooting percentage and measures of root quality indicating the effects of fertility on rooting response differed depending
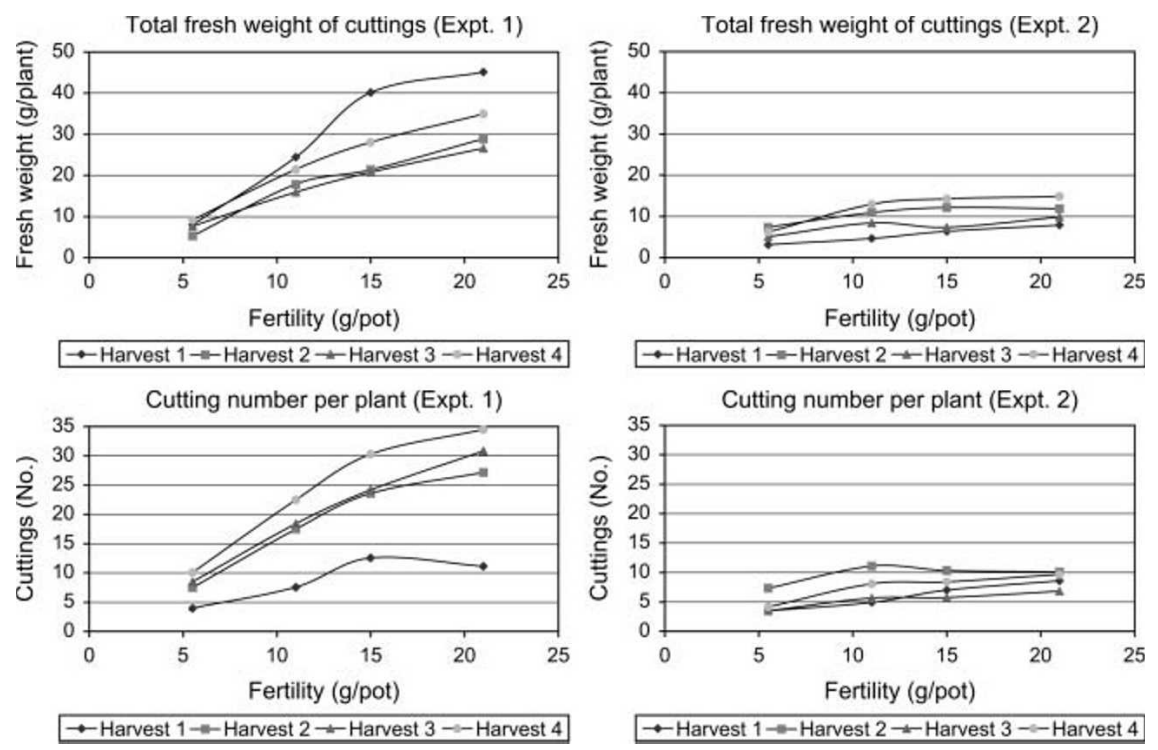

Fig. 2. Total fresh weight of cuttings harvested per stock plant and mean number of cuttings produced per stock plant for seacoast marshelder planted $3 \mathrm{Feb} .2004$ (Expt. 1) and 9 July 2004 (Expt. 2) fertilized at 5.5, 11, 15, or $21 \mathrm{~g}$ of $15 \mathrm{~N}-3.9 \mathrm{P}-$ 10K controlled-release fertilizer [Osmocote Plus, 8- to 9-month formulation at $70{ }^{\circ} \mathrm{F}\left(21.1^{\circ} \mathrm{C}\right)$; Scotts Miracle-Grow, Marysville, $\left.\mathrm{OH}\right]$ per 1 -gal $(3.8 \mathrm{~L})$ pot and hedged monthly (May to August and August to November) to harvest cuttings $(1 \mathrm{~g}=0.0353 \mathrm{oz})$.

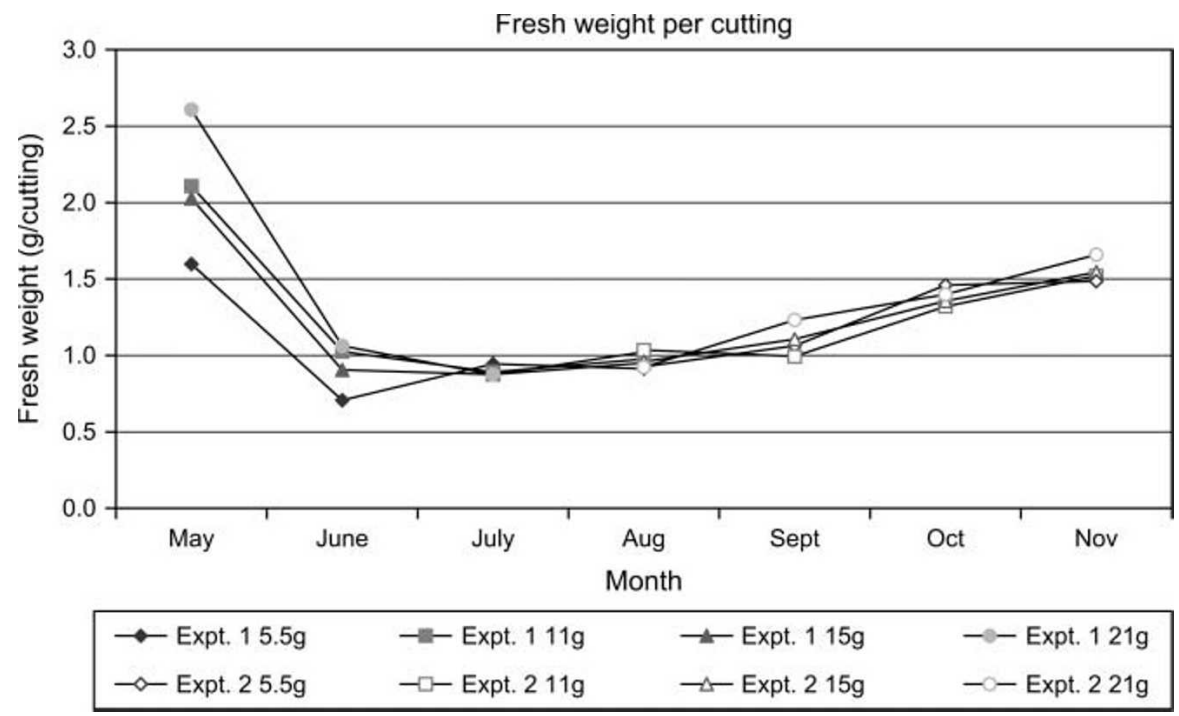

Fig. 3. Mean fresh weight of individual cuttings from seacoast marshelder stock plants planted 3 Feb. 2004 (Expt. 1) and 9 July 2004 (Expt. 2) fertilized at 5.5, 11 , 15 , or $21 \mathrm{~g}$ of $15 \mathrm{~N}-3.9 \mathrm{P}-10 \mathrm{~K}$ controlled-release fertilizer [Osmocote Plus, 8- to 9-month formulation at $70^{\circ} \mathrm{F}\left(21.1{ }^{\circ} \mathrm{C}\right)$; Scotts Miracle-Grow, Marysville, $\left.\mathrm{OH}\right]$ per 1-gal $(3.8 \mathrm{~L})$ pot and hedged monthly (May to August and August to November) to harvest cuttings $(1 \mathrm{~g}=0.0353 \mathrm{oz})$.

on the time of harvest. Percent rooting was influenced by fertility rate $(P=$ $0.0035)$ and the time of harvest $(P<$ 0.0001 ) (Fig. 4). Percent rooting did not increase in response to an increase in fertility rate for any harvest period. Rooting percentages for May and
June were between $88 \%$ and $100 \%$ for all fertility levels. Regression analyses indicate a negative linear relationship between fertility rate and rooting percentages for July and August. Rooting percentages for June ranged from $79 \%$ at $5.5 \mathrm{~g}$ to $54 \%$ at 

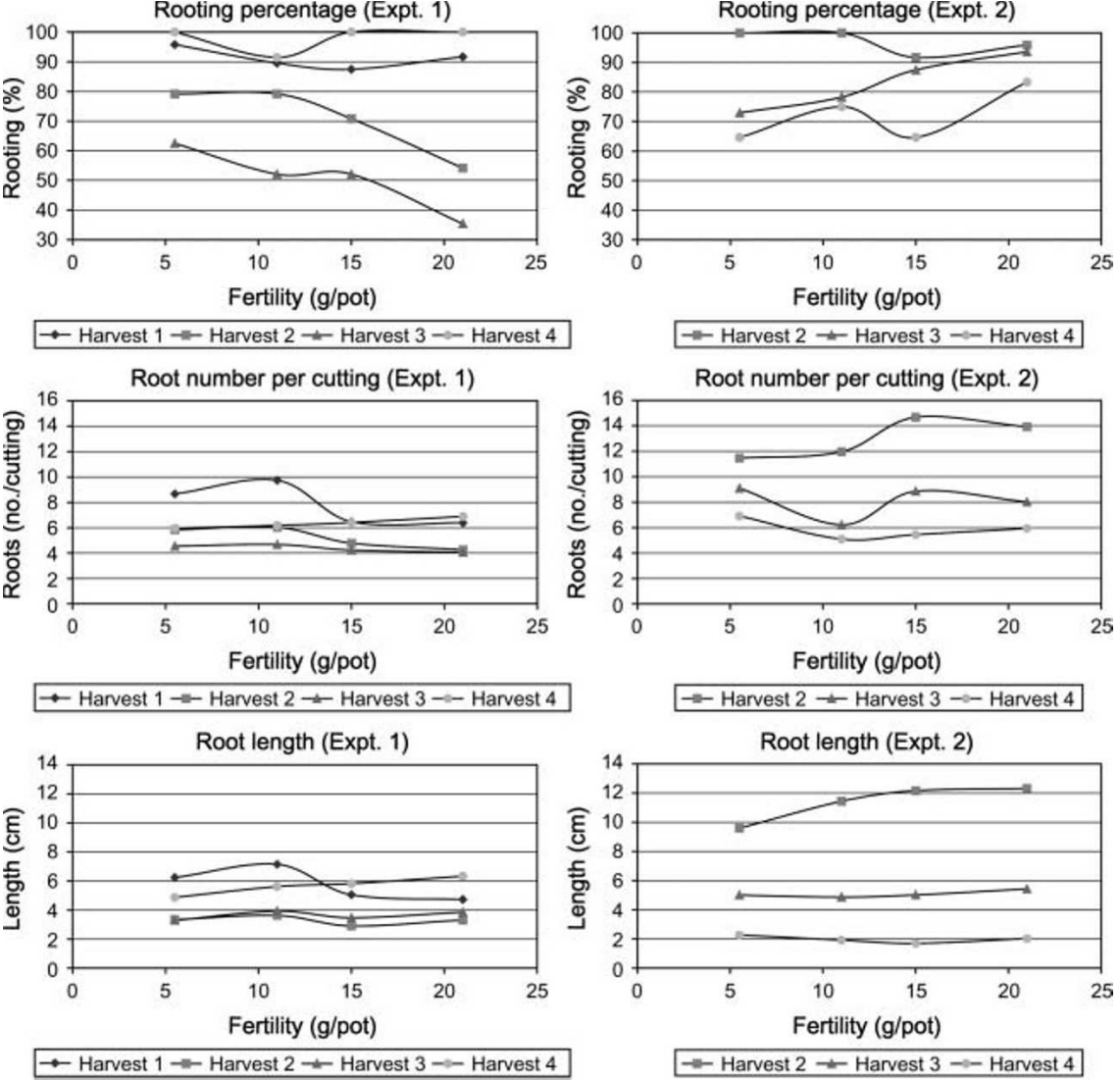

Fig. 4. Mean rooting percentage, root number, and root length for seacoast marshelder cuttings from stock plants planted 3 Feb. 2004 (Expt. 1) and 9 July 2004 (Expt. 2) fertilized at 5.5, 11, 15, or $21 \mathrm{~g}$ of $15 \mathrm{~N}-3.9 \mathrm{P}-10 \mathrm{~K}$ controlledrelease fertilizer [Osmocote Plus, 8- to 9-month formulation at $70{ }^{\circ} \mathrm{F}\left(21.1{ }^{\circ} \mathrm{C}\right)$; Scotts Miracle-Grow, Marysville, $\mathrm{OH}$ ] per 1-gal $(3.8 \mathrm{~L})$ pot and hedged monthly (May to August and August to November) to harvest cuttings $(1 \mathrm{~cm}=0.3937 \mathrm{inch})$.

$21 \mathrm{~g}$, whereas rooting percentages for July ranged from $63 \%$ at $5.5 \mathrm{~g}$ to $35 \%$ at $21 \mathrm{~g}$. An increased fertility rate for seacoast marshelder stock plants did not increase the rooting percentage of harvested cuttings.

Fertility rate had a significant effect on the number of roots per cutting $(P=0.016)$ but did not influence root length $(P=0.0772)$ (Fig. 4). In May, root number declined linearly as fertility rate increased and ranged from 8.6 roots per cutting at $5.5 \mathrm{~g}$ to 6.3 roots per cutting at $21 \mathrm{~g}$. Root number did not differ in response to fertility rate from June to August with 4.3 to 6.9 roots produced per cutting.

\section{Expt. 2: Actively growing transplants}

STOCK PLANT GROWTH AND CUTTING PRODUCTION. For stock plants initiated in the spring from actively growing transplants, the main effects of fertility and time of harvest both had a significant effect on stock plant width and growth index but did not have a significant effect on stock plant height. There were no significant interactions between the effects of fertility and time of harvest for height, width, growth index, cutting number, or weight of individual cuttings. Pearson correlation coefficients indicate stock plant height and width were not correlated, although width was highly correlated with growth index $(\mathrm{r}=0.7803)$.

Fertility rate had no effect on stock plant height (Fig. 1), but decreases in stock plant height after each harvest of cuttings indicate plant regrowth was affected by the time of harvest $(P<0.0001)$. Stock plant fertility did have a significant effect $(P<0.0001)$ on stock plant width (Fig. 1). Compared with the 11-g rate, there was a significant decrease in stock plant width for all harvest periods when fertility rate decreased to $5.5 \mathrm{~g}$. Stock plant width remained nearly constant after each successive harvest of cuttings when fertilizer was applied at $5.5 \mathrm{~g}$. Stock plant width increased with each subsequent harvest of cuttings when the fertilizer was applied at 11 to $21 \mathrm{~g}$. However, the stock plant width did not differ among plants fertilized at 11,15 , or $21 \mathrm{~g}$.

Fertility rate $(P<0.0001)$ and time of harvest $(P=0.0004)$ both had a significant effect on plant growth index. Plant growth index demonstrated a linear or quadratic increase as fertilizer rate increased. The greatest increase in plant growth index occurred from 5.5 to $11 \mathrm{~g}$ and no significant increase in plant index was evident from 11 to $21 \mathrm{~g}$ (Fig. 1 ).

Fertility rate as well as time of harvest had a significant effect on the total fresh weight of cuttings removed from each plant $(P<$ $0.0001)$. The total fresh weight of cuttings produced per stock plant increased linearly with an increase in fertilizer rate for all harvests (Fig. 2). Total fresh weight of cuttings produced per plant decreased $23 \%$ from September to October causing an interaction between fertilizer rate and harvest period. However, overall, total fresh weight of cuttings produced per stock plant increased $178 \%$ from August to November at the $11-g$ rate.

Fertility rate $(P<0.0001)$ and time of harvest $(P<0.0001)$ had a significant effect on the number of cuttings harvested, and there was no interaction between fertility rate and harvest date. Regression analyses indicated cutting number increased linearly as fertility rate increased (Fig. 2). Reducing the fertilizer rate to $5.5 \mathrm{~g}$ resulted in a $29 \%$ to $48 \%$ decrease in cutting production. However, fertilizer rates greater than $1 \mathrm{lg}$ did not increase the number of cuttings produced per plant. Cutting number increased between August and September, decreased by October, and increased between October and November, but did not recover to the number of cuttings produced in September. Fertility rate did not have a significant effect on mean cutting weight $(P=0.3750)$, but cutting weight did increase from August to November $(P<0.0001)$ (Fig. 3).

RoOTING PERCENTAges AND QUALITY. An interaction was present between the main effects of fertility and time of harvest for all rooting 
variables indicating the rooting response to fertility differed depending on the time of harvest. Percent rooting was influenced by fertility rate $(P=0.0269)$ and the time of harvest $(P<0.0001)$ (Fig. 4). Rooting percentages for cuttings collected in September remained above $90 \%$ regardless of the level of stock plant fertility. In October, rooting percentages increased linearly as the rate of stock plant fertility increased resulting in a $28 \%$ increase in rooting percentage from the 11 - to 21 -g rate. Rooting percentages and stock plant fertility continued to demonstrate a positive linear relationship in November with rooting percentages ranging from $64 \%$ to $83 \%$.

Both fertility rate $(P=0.0059)$ and time of harvest $(P<0.0001)$ had a significant effect on mean root number per cutting. In September, the number of roots per cutting initially increased as stock plant fertilizer rate increased, but this trend reversed by November (Fig. 4). The number of roots per cutting was $21 \%$ to $63 \%$ higher in September than for subsequent harvests.

Mean root length was not affected by the rate of stock plant fertilizer $(P=0.2079)$; however, root length did differ with the time of harvest $(P<0.0001)$. Root length was significantly higher in September compared with subsequent harvests (Fig. 4). Root length decreased from 10 to $12 \mathrm{~cm}$ in September to only $2 \mathrm{~cm}$ by November.

\section{Discussion}

Maximum stock plant growth was achieved with an application of 11 to $15 \mathrm{~g}$ of controlled-release fertilizer. Plant growth before the first harvest of cuttings from both experiments exhibited an increase in growth in response to an increase in fertilizer rate (Fig. 1). In both experiments, the greatest increase in growth (both height and width) occurred when the fertilizer rate increased from $\mathbf{5 . 5}$ to $11 \mathrm{~g}$. Growth increases were also evident when the fertilizer rate increased from 11 to $15 \mathrm{~g}$, but not from 15 to $21 \mathrm{~g}$. These results indicate the growth rate of seacoast marshelder increased with the application of controlled-release fertilizer up to the 15-g rate, but no additional benefit in growth was achieved with further increases in the rate of fertilization.
A correlation between increased stock plant width and increased cutting number suggests that managing stock plants in a manner that increases width will increase cutting production. After the first harvest of cuttings for both experiments, subsequent growth in plant height rarely achieved the initial height of the first harvest at the 11 - to $21-\mathrm{g}$ fertilizer rates. Although recovery of plant height after pruning generally decreased over time at 11 to $21 \mathrm{~g}$, plant width continued to increase after pruning regardless of fertility rate. Stock plant width increased with each successive harvest and was highly correlated with an increase in the number of cuttings produced. Cutting production has also been shown to increase with successive harvests in snapdragon (Antirrbinum), yellow buttons (Chrysocephalum), twinspur (Diascia), lavender (Lavendula), african daisy (Osteospermum), and verbena (Verbena) in response to hedging, demonstrating that hedging of stock plants can result in an increase in cutting number (Faust and Grimes, 2005). Increasing the hedging height in successive harvests was also found to maximize cutting production (Faust and Grimes, 2005). Seacoast marshelder stock plants were hedged to a constant height in our experiments, but further increases in the number of cuttings produced may have been realized with successive increases in stock plant height after each harvest. Over a 23-week period, cutting quantity and quality of fan flower (Scaevola) cuttings were shown to increase over time as $\mathrm{N}$ fertilization concentration increased from 100 to $300 \mathrm{mg} \cdot \mathrm{L}^{-1}$ (Gibson, 2003 ). Similarly, stock plants of geranium were shown to produce low numbers of cuttings at $50 \mathrm{mg} \cdot \mathrm{L}^{-1} \mathrm{~N}$ while producing higher numbers of cuttings at 100,200 , and $400 \mathrm{mg} \cdot \mathrm{L}^{-1}$ $\mathrm{N}$ (Ganmore-Neuman and Hagiladi, 1990, 1992).

Time of harvest had a greater influence on the weight of individual cuttings than did the rate of fertilizer. When cutting weight is graphed across time (Fig. 2), the lowest weights per cutting were evident during the months of June and July (Expt. 1, harvests 2 and 3 ) and corresponds with the period of lowest rooting percentages, particularly at the highest fertility rate. Seasonal changes in cutting weight, which show the lowest cutting weight at the time of the poorest rooting responses (June and July) regardless of the stock plant fertility regime, suggests collection of cuttings should be avoided at these times. It is not known if the rapid spring growth after the prior harvest of cuttings and subsequent stock plant hedging results in shoots too low in carbohydrates, nutrients, or other rooting cofactors, which result in the lower rooting percentages. A similar seasonal decrease in rooting percentage was reported by Rowe et al. (2002) in which May (spring softwood), July (summer softwood), and January (winter hardwood) terminal stem cuttings of loblolly pine (Pinus taeda) were propagated from hedged stock plants. Spring cuttings rooted in the highest percentages $(59.5 \%)$ followed by winter $(40.5 \%)$ and summer softwood $(34.7 \%)$. However, neither total nonstructural carbohydrates (TNC) nor any of several specific carbohydrates were correlated with rooting, and an optimal TNC:N ratio for rooting was not found.

Stock plant nutrition has been shown to have a significant effect on rooting percentages (Blazich, 1988; Veierskov, 1988), as was observed in this study. Rooting percentage had an inverse relationship with fertility rate from May through July suggesting high levels of fertility should be avoided during that period to keep from negatively affecting rooting percentages. High levels of fertility, which may be optimal for plant growth and cutting production, had a negative affect on rooting percentages, root number, and root length. This inverse relationship has also been demonstrated in cuttings taken from stock plants of geranium, azalea, and eastern red cedar (Haun and Cornell, 1951; Henry et al., 1992; Preston et al., 1953). Haun and Cornell (1951), Henry et al. (1992), and Preston et al. (1953) all found inverse relationships between stock plant fertilization and rooting percentages in cuttings harvested from stock plants. With seacoast marshelder, this trend was not consistent throughout the season. Higher fertilizer rates had a neutral to positive effect on seacoast marshelder rooting percentage and root quality during the months of August through November. 


\section{Conclusions}

The recommended rate of $11 \mathrm{~g}$ of controlled-release fertilizer per l-gal pot produced nearly maximum plant growth and resulted in acceptable rooting percentages (greater than $70 \%$ ) throughout the growing season. When stock plants were established with dormant liners, optimum rooting percentages occurred from May to early June and August, whereas with stock plants established with actively growing liners, optimum rooting percentages occurred from September through November. Using a stock plant hedging technique was a successful method for the production of seacoast marshelder cuttings. Propagators should prune stock plants to maximize plant width during spring and schedule a harvest of cuttings from May to early June. After this initial harvest of cuttings, stock plants may benefit from a period of growth during July when rooting percentages are minimal. By avoiding cutting harvests during July, cutting production will be maximized and cuttings will be propagated at a time when cuttings root at a higher percentage. Avoiding harvest and propagation of cuttings when rooting percentages will be at their lowest will improve propagation success and increase production efficiency.

\section{Literature cited}

Blazich, F.A. 1988. Mineral nutrition and adventitious rooting, p. 61-69. In: Davis, T.D., B.E. Haissig, and N. Sankhla (eds.). Adventitious root formation in cuttings. Dioscorides Press, Portland, OR.
Colosi, J.C. and J.F. McCormick. 1978 Population structure of Iva imbricata in 5 coastal dune habitats. Bul. Torrey Bot. Club 105:175-186.

Craig, R.M. 1991. Plants for coastal dunes of the Gulf and south Atlantic coasts and Puerto Rico. U.S. Dept. Agr., Soil Conservation Serv., Agr. Info. Bul. 460.

Faust, J.E. and L.W. Grimes. 2005. Pinch height of stock plants during scaffold development affects cutting production. HortScience 40:650-653.

Franks, S.J. 2003. Competitive and facilitative interactions within and between two species of coastal dune perennials. Can. J. Bot. 81:330-337.

Ganmore-Neuman, R. and A. Hagiladi. 1990. Effect of the $\mathrm{NO}_{3}^{-} / \mathrm{NH}_{4}{ }^{+}$ratio in nutrient solution on Pelargonium stock plants. Yield and quality of cuttings. J. Plant Nutr. 13:1241-1256.

Ganmore-Neuman, R. and A. Hagiladi. 1992. Plant growth and cutting production of container grown Pelargonium stock plants as affected by $\mathrm{N}$ concentration and $\mathrm{N}$ form. J. Amer. Soc. Hort. Sci. 117:234-238.

Gibson, J.L. 2003. Influence of mineral nutrition on stock plant yield and subsequent rooting of stem cuttings of Scaevola, new guinea impatiens, and vegetative strawflower. North Carolina State Univ., Raleigh, PhD Diss.

Haun, J.R. and P.W. Cornell. 1951. Rooting response of geranium (Pelargonium hortorum, Bailey var. Richard) cuttings as influenced by nitrogen, phosphorus, and potassium nutrition on the stock plant. Proc. Amer. Soc. of Hort. Sci. 58:317-323.
Henry, P.H., F.A. Blazich, and L.E. Hinesley. 1992. Nitrogen nutrition of containerized eastern redcedar 2 . Influence of stock plant fertility on adventitious rooting of stem cuttings. J. Amer. Soc. Hort. Sci. 117:568-570.

Moyers, J.E. 1996. Food habits of Gulf Coast subspecies of beach mice (Peromyscus polionotus spp.). Auburn Univ., Auburn, AL., MS Thesis.

Preston, W.H., Jr., J.B. Shanks, and P.W. Cornell. 1953. Influence of mineral nutrition on production, rooting and survival of cuttings of azaleas. Proc. Amer. Soc. Hort. Sci. 61:499-507.

Rowe, D.B., F.A. Blazich, B. Goldfarb, and F.C. Wise. 2002. Nitrogen nutrition of hedged stock plants of loblolly pine. II. Influence of carbohydrate and nitrogen status on adventitious rooting of stem cuttings. New For. 24:53-65.

Thetford, M. and D.L. Miller. 2002. Propagation of 4 Florida coastal dune species. Native Plants J. 3:112-120.

Van der Valk, A.G. 1974. Environmental factors controlling the distribution of forbs on coastal foredunes in Cape Hatteras National Seashore. Can. J. Bot. 52:1057-1073.

Veierskov, B. 1988. Relations between carbohydrates and adventitious root formation, p. 70-78. In: Davis, T.D., B.E. Haissig, and N. Sankhla (eds.). Adventitious root formation in cuttings. Dioscorides Press, Portland, OR.

Woodhouse, W.W. 1982. Creation and restoration of coastal plant communities. CRC Press, Boca Raton, FL. 